NAVA BAR

University of Haifa, Israel

\title{
THE MODEL \\ OF PROFESSIONAL DEVELOPMENT SCHOOL (PDS) AS A PRACTICE OF PARTNERSHIP UNIVERSITY-SCHOOLS IN TEACHER EDUCATION: A MULTI-YEAR EVALUATION STUDY IN ISRAEL
}

\begin{abstract}
Bar Nava, The Model of Professional Development School (PDS) as a Practice of Partnership University-Schools in Teacher Education: A Multi-year Evaluation Study in Israel [Model szkół kształcących nauczycieli jako praktyka partnerstwa pomiędzy uniwersytetami i szkołami kształcącymi nauczycieli i pedagogów: wieloletnie badanie ewaluacyjne w Izraelu]. Studia Edukacyjne nr 42, 2016, Poznań 2016, pp. 453-469. Adam Mickiewicz University Press. ISSN 1233-6688. DOI: $10.14746 /$ se.2016.42.26
\end{abstract}

The article presents in its first part the partnership model - PDS (Professional Development School) for teacher education that developed in the 1970s in the United States following criticism and research findings that indicated lack of satisfaction with the traditional teacher education programs. In its second part the article presents findings and discussion of a multi-year study conducted over seven years, from 2010 to 2016, in the first and up till now the only PDS partnership incorporated into teacher training program in research university in Israel. The multi-year study focused on student teachers' evaluation of the contribution of the teacher training components of the universityschool partnership model (PDS) to their learning of teaching: the practice teaching in the school and the school mentors; the groups of student colleagues as learning communities and their weekly meetings and the university coordinators. From the perception of the PDS partnership as a dynamic and developing process and from the approach of evidence-based practice, the importance of this multi-year study lies in the identification of the essential strengths in the process of the practical experience expressed in the partnerships for their empowerment. In addition the importance of this research is in the identification of the essential weaknesses and challenges, for the purpose of enquiry and learning in the learning communities who take part in the PDS partnerships, and the raising of the necessary courses of action and changes. The importance of the research study in the international aspect lies in the presentation of an additional profile of partnership for the extension of the shared discussion about dilemmas and challenges that arise from the implementation of different partnerships in the training of teachers.

Key words: teacher education, teacher training, Professional Development School - PDS, partnership 


\section{Introduction}

The teaching profession and the teacher education are found in a crisis in many countries in the Western world, including Israel. Comprehensive research studies conducted in the schools and in the teacher education institutions in the United States indicated the need for the implementation of reforms in teacher education and in the educational systems themselves. ${ }^{1}$ The criticism and research findings that indicated the lack of satisfaction with the traditional teacher education programs, with the teachers' professional development, and with the students' achievements, caused the growth, in the 1970 s in the United States, of the idea of partnership between the teacher education institutions and the schools called PDS (professional development schools). ${ }^{2}$ The aim of the idea of the partnership was to improve the education overall. The assumption was that the improvement in the teacher education would lead to a rise in the level of the teaching and in the students' achievements. ${ }^{3}$ The conceptual framework for the idea of the partnership was created in the year 1986, by the Holmes Group ${ }^{4}$ (1986), whose members understood that the improvement of the processes of the practical training depends simultaneously both on the school renewal and the improvement in the teaching and learning processes and on the re-structuring of the practices in the field and the improvement of the training for teaching. ${ }^{5}$

The perception of teaching as an academic - practical oriented profession places the practical training at the center of the training for teaching. Research studies indicate that the knowledge of the teaching is acquired and

1 J. Goodlad, Educational renewal: Better teachers, better schools, San Francisco 1994; M. Zilberstein, M. Ben Peretz, From individual cases to the shared elements in the constellation of the creation of partnerships, [in:] New trend in the training programs of teachers: Partnership between colleges and schools - the Israeli story, Eds M. Zilbershtein, M. Ben-Peretz, N. Greenfeld, Tel Aviv 2006, p. 437-476; T. Ariav, The training for teaching: A picture of the situation in the world and in Israel and a look to the future, [in:] The crisis in teacher education: Reasons, problems and possible solution, Eds D. Kfir, T. Ariav, Tel Aviv 2008, p. 19-55.

2 J. Goodlad, Educational renewal; M. Zellermayer, Partnership as a professional research learning community: Review of the Literature, [in:] In First person: Partnership in the college field, Eds A. Margolin, M. Zellermayer, Tel Aviv 2005, p. 11-27.

${ }^{3}$ T. Ariav, K. Smith, Creation of partnerships between teacher education institutions and the field: An International look with emphasis on the professional development school (PDS), [in:] New trend in the training programs of teachers: Partnership between colleges and schools - the Israeli story, Eds M. Zilbershtein, M. Ben-Peretz, N. Greenfeld, Tel Aviv 2006, p. 21-67; T. Ariav, The Training for Teaching.

${ }^{4}$ Holmes Group, Tomorrow's teachers. A report of the Holmes Group. East Lansing, MI: Holmes Group, 1986.

${ }^{5}$ M. Zilberstein, M. Ben Peretz, From individual cases to the shared elements. 
develops primarily through the practical training ${ }^{6}$ and that a distinction should be drawn between knowledge of teaching and knowledge on teaching.7 It was further found that the practice is a significant factor in the training of the student for teaching for his designated role, and it constitutes a main focus in the process of his professional development and in the formation of his professional identity. ${ }^{8}$ There is an agreement that it is necessary to tighten the relationship between the academia and the practice and to expose the teacher students to the school activity in its different aspects and components, through the direction to the implementation of metacognitive reflective processes in all stages of the teaching and experience. ${ }^{9}$ There are two prevailing main models of practice-oriented training: the traditional model and the partnership model PDS (professional development school).

The perception of the traditional approach to the training of student teachers is that the academic institution inculcates theoretical knowledge, while the field provides the practical knowledge. ${ }^{10}$ The teaching is perceived as a regular practical occupation in which the students gain experience in the school to practice and implement the theory of teaching learned in the academic institution. ${ }^{11}$ The widespread assumption in the traditional training model was that teaching and the training process for teaching must be based on the disciplinary perspectives, ${ }^{12}$ focus on the subject matter, on knowledge, ${ }^{13}$ which reduces the possibilities of the enquiry of the teaching and the learning from different and diverse viewpoints. The practical training in the traditional model is limited to few numbers of hours in comparison to the hours allotted for the academic learning. The student is supported by a pedagogical instructor from the training institution arrives only a number

${ }^{6}$ M. Zilbershtein, R. Panvevsky, E. Goz, The triangle of instruction: Pedagogical instructorstudent-mentor teacher, a recipe for success or failure, Tel Aviv 2005.

7 T. Ariav, K. Smith, Creation of partnerships, p. 23.

8 Ibidem.

${ }^{9} \mathrm{~K}$. Waege, O. Haugalokken, Research-based hands-on practical teacher education: An attempt to combine the two, Journal of Education for Teaching, 2013, 39(2), p. 235-249.

${ }^{10} \mathrm{~F}$. Korthagen, J. Kessels, Linking theory and practice: Changing the pedagogy of teacher education, educational researcher, Educational Researcher, 1999, 28, 4, p. 4-17; S. Avdor, The changed required in the characteristics of the candidates for teaching, in their training and in their professional development, [in:] The crisis in teacher education: Reasons, problems and possible solution, Eds D. Kfir, T. Ariav, Tel Aviv 2008, p. 145-175.

${ }^{11}$ M. Zilberstein, M. Ben Peretz, From individual cases to the shared elements.

12 L.S. Shulman, Knowledge and teaching: Foundations of the new reform, Harvard Educational Review, 1987, 57(1), p. 1-22.

13 A. Kizel, Pedagogies of reflection: Dialogical professional-development schools in Israel, [in:] International teacher education: Promising pedagogies (Part A) (Advances in research on teaching, volume 22), Eds C.J. Craig, L. Orland-Barak, Emerald Group Publishing Limited, 2014, p. 113-136. 
of times a year for the aim of assessing the student. The student's main experience is in the class of the mentor teacher who teaches the subject matter, the discipline, in which the student is training to teach. Insignificant focus is given to interpretative reflective processes. The disconnection between the academic and the practice is one of the weaknesses of the traditional programs for the training of teachers, in which clear and open connections between the practical teaching and the pedagogical theories that nourish it are missing and thus the traditional training programs remain, occasionally, only on an intuitive level. ${ }^{14}$

\section{The Training of Teachers in the Partnership Model - PDS Partnership as the Basis of the PDS Model}

Examination of the traditional model for the training of teachers and insights that arose from the research findings led to the search for alternative models of the training of teachers. In the past two decades there is increasing recognition that partnerships with schools may create significant pragmatic changes both in the programs of teacher training and in the school system. ${ }^{15}$ The aspiration is to bridge through the partnerships between two cultures, the culture of the academia that represents the knowledge based on research and educational philosophy, and the school culture that represents the professional practice and experience, and to create a third culture, a culture of learning and professional development of teacher students and of teachers in the school. ${ }^{16}$ A culture of partnership. ${ }^{17}$ The training for teaching according to the PDS model is applied in actuality between the training institutions, the colleges and universities, and the schools, where the practice of the student teachers is held. The training according to this model is a process in which the principle of partnership is a leading value and a basis for the promotion of all the involved parties. The responsibility for this process is

${ }^{14} \mathrm{~S}$. Avdor, The changed required in the characteristics of the candidates for teaching.

15 Holmes Group, Tomorrow's schools: Principles for the design of professional development schools, East Lansing, MI: Holmes Group, 1990; M. Zilberstein, M. Ben Peretz, From individual cases to the shared elements.

16 A. Lieberman, Networks as learning communities, Journal of Teachers Education, 2000, 51, p. 221-227; M. Zilberstein, M. Ben Peretz, From individual cases to the shared elements.

${ }^{17} \mathrm{~S}$. Milat, The pedagogical instructor - A main figure in the creation of partnership between the colleges and the schools (PDS), [in:] A new review of the learning program of the specialization in pedagogical instruction: Work paper number 2, Eds M. Zilbershtein, R. Reichenberg, Tel Aviv 2005. 
on all the partners together. ${ }^{18}$ This perception of an academia-field partnership presents complex network of relations of commitment and responsibility and not a one-way system of relations in which the academic influences the field, or a two-way relation, in which each one influences the other. ${ }^{19}$

\section{From Theory to Practice in the PDS Model}

The establishment of PDS partnerships led to a significant change in the nature of the teacher training in comparison to the practice in the traditional model. According to the PDS model, the teaching is a practical-reflective engagement learned through doing in the complicated authentic reality of the school. ${ }^{20}$ The practice is in the center of the training of the students in the field, from the assumption that learning occurs only from experience and doing. The school serves as an organizational framework that enables an authentic and realistic environment for training, in which it is possible to direct the interaction with the student and to support him broadly in the encounter with different aspects in the teaching roles. ${ }^{21}$ While the experience in the traditional model focuses on the subject matter, on the discipline, the partnership model PDS focuses on the individual student and his unique needs. ${ }^{22}$

In actuality, a group of student teachers from different disciplines comes throughout the year to the school, a day or two days on a weekly basis, accompanied by a pedagogical coordinator from the training institution, and integrates into the life of the school. The practice in the school includes a number of components that enable the student teachers to observe and to actively experience a constellation of aspects of the teacher's work. ${ }^{23}$ Thus the PDS model increases the teaching students' opportunities for learning and allows them to learn, to explore, and to attain insights from different fields that are not just disciplinary - didactics, pedagogy, disciplinary, ${ }^{24}$ the

$18 \mathrm{~T}$. Ariav, The Training for Teaching.

${ }^{19} \mathrm{E}$. Wenger, Communities of practice: Learning, meaning and identity, Cambridge University Press, Cambridge, 1998; M. Zellermayer, Partnership as a professional research learning community.

${ }^{20}$ D.A. Schon, Coaching reflective teaching, [in:] Reflection in teacher education, eds P.P Griment, G.L. Erikson, New York 1988; S. Avdor, The changed required in the characteristics of the candidates for teaching.

21 S. Milat, The pedagogical instructor.

22 A. Kizel, Pedagogies of reflection.

${ }^{23} \mathrm{H}$. Sagee, Individualized mentoring as a developing initiative during the training of the students for teaching, [in:] Everything is a matter of initiative: Initiatives that promote professional developments in field-college partnership settings, Eds A. Kliger, A. Hoffman, Tel Aviv 2013, p. 19-61.

${ }^{24}$ A. Kizel, Pedagogies of Reflection. 
school, and the class. ${ }^{25}$ The components of the practices in the school include: (1) Observation and active experience of the student in the diverse teaching-learning processes that are held in the class; (2) Participation of the student in the school activities, such as parents' meetings, trips and more; (3) Exposure of the student to the variety of the teacher's and the homeroom teacher's roles, such as teamwork, individualized work with the student, relationship with the parents and additional roles; (4) Recognition of the organizational structure of the school in its different aspects and role-holders in the school; (5) Development of a professional discourse with those involved in the partnership at the diverse opportunities that the school arena offers.

\section{Uniqueness of the Teacher Training in the PDS Model}

Russell (2002)26 maintains that the PDS challenges the hierarchy in which the student is found at the bottom. All the involved parties in the training according to the PDS model are a part of one learner community ${ }^{27}$ - teaching students, instructors from the training institution, mentor teachers from the school, the principal and the management staff, the liaison person from the school and roles-holders in the school. Through the students' participation in learning communities there is collegiality among all the partners. ${ }^{28}$ Each one of the partners in the community of learners is responsible to promote his learning and the others' learning, to examine the knowledge and to create new understandings. ${ }^{29}$ The practical training in the PDS model focuses on general learning-teaching issues and not only on disciplinary ones. The practical training emphasizes the development and implementation of metacognitive reflective processes that occur in the multidisciplinary learning community at all stages of the learning-teaching, from the stage of the planning, through the performance, and to the reflection on the experience. The

${ }^{25}$ L. Darling-Hammond, K. Hammerness, The design of teacher education programs, [in:] Preparing teachers for a changing world: what teachers should learn and be able to do, Eds L. DarlingHammond, J. Bransford, San-Francisco 2005, p. 390-461.

26 T. Ariav, K. Smith, Creation of partnerships between teacher education institutions and the field, p. 47.

${ }^{27}$ M. Levine, Why invest in professional development schools? Educational Leadership, 2002, 59(6), p. 65-68.

${ }^{28}$ T. Ariav, K. Smith, Creation of partnerships between teacher education institutions and the field.

${ }^{29}$ L. Orland-Barak, Learning to mentor-as-praxis: Foundations for a curriculum in teacher education, New York 2010; M.T. Buchanan, L.J. Stern, Pre-service Teachers' Perceptions of the Peer Review, Journal of Education for Teaching, 2012, 38(1), p. 37-49. 
PDS model focuses on the development of academic-practical reflective dialogue through the creation of a planned and painstaking integration of practical knowledge that originates in experience with knowledge that originates in research, scientific theory, and educational approaches. The theoretical knowledge that is learned serves as an interpretation tool for the practice in the field. ${ }^{30}$ The reflection in the framework of the practices is a part of the teaching student's work routine and is conducted in a dialogue manner between him and himself, with his colleagues from the learning community who have greater experience - mentor teachers or instructors, and the peer group. Reflection takes place with a critical examination of what occurs in the school. In this way, the real complexity of teaching is perceived. ${ }^{31}$ The assumption is that the integration of the dialogue with the reflection in the framework of enquiry, in the multidisciplinary community, enables the raising of viewpoints from different disciplines and perspectives and the development of a perception of learning as an enquiry and critical process for the teacher student. ${ }^{32}$ Kizel (2014) ${ }^{33}$ proposed the concept of DRPDS, Pedagogies of Reflection: Dialogical Professional Development Schools - PDS, as a concept that reflects the nature of the training in the PDS model and its uniqueness.

\section{Partnership University-Schools (PDS): A Multi-year Study in Israel Context}

In Israel, like in other places in the world, the recognition of the need for change in the manner of the teacher training has increased. For more than a decade initiatives have developed in some of the colleges of education in Israel to create partnerships with the schools. In the universities the curriculum in teacher training has continued to operate according to the traditional model that emphasizes the teaching of the discipline. This part will present A multi-year study conducted over seven years, from 2010 to 2016, on the topic of student teachers' evaluation of their practice teaching in the context

$30 \mathrm{~S}$. Avdor, The changed required in the characteristics of the candidates for teaching; A. Kizel, Pedagogies of reflection.

$31 \mathrm{~S}$. Beck, Is training really unnecessary? On the uniqueness of academic training of teachers, [in:] The crisis in teacher education: Reasons, problems and possible solution, Eds D. Kfir, T. Ariav, Van Leer, Tel Aviv 2008, p. 251-280.

32 S. Nikitina, Pathways of interdisciplinary cognition, Cognition and Instruction, 2005, 23(3), p. 389-425.

${ }^{33}$ A. Kizel, Pedagogies of reflection, p. 113. 
of a university-school partnership model - PDS, incorporated for the first time into a teacher training program in university in Israel.

Seven to nine partnerships participated in the program each year, depending on number of student teachers and budgetary considerations. Each PDS partnership consisting 10-20 student teachers from different teaching disciplines, learning on weekly basis, along the academic training period, in a Middle School or High School, according to the cultural sector to which they belong - Hebrew-speaking or Arab-speaking. Pedagogical PDS coordinators, appointed by the university, guide the student teachers throughout the training day and are the contact persons between the university and the schools. One of the important activities of the PDS coordinators is leading of weekly regular meetings with student teachers practicing at the school. In these meetings pedagogical cases and issues, occurred in the encounters with the class and the school environment, are raised by the student teachers, analyzed in reflectively and critically manner, emphasizing the links between theory and practice.

\section{Method}

\section{The multiyear study question}

The question that led the multi-year evaluation study is how do student teachers evaluate the contribution of the PDS teacher training components to their learning of teaching?

This question sought to evaluate the contribution of the three components of the PDS university-school partnership model:

1. The practice teaching in the school and the mentors.

2. The groups of student colleagues as learning communities and their weekly meetings.

3. The university coordinators.

\section{Research participants and research tool}

A quantitative questionnaire of 34 statements on a five-point Likert scale was developed to address the question and was delivered to the students taking part in the PDS program at the end of each academic year. The par- 
ticipation rate of the student teachers in the evaluation study throughout the years 2010-2016 was 87\% (Table 1).

Table1

The multi-year participation rate of the student teachers in the evaluation study: The years $2010-2016$

\begin{tabular}{|c|c|c|c|}
\hline The year & $\begin{array}{c}\text { Annual program } \\
\text { students }\end{array}$ & $\begin{array}{c}\text { Annual question- } \\
\text { naire respondents }\end{array}$ & $\begin{array}{c}\text { Annual question- } \\
\text { naire respondents } \\
\text { percentage }\end{array}$ \\
\hline 2010 & 141 & 126 & $89 \%$ \\
2011 & 128 & 118 & $92 \%$ \\
2012 & 163 & 134 & $82 \%$ \\
2013 & 135 & 111 & $82 \%$ \\
2014 & 108 & 105 & $97 \%$ \\
2015 & 122 & 102 & $84 \%$ \\
2016 & 97 & 85 & $88 \%$ \\
\hline Total 2010-2016 & 894 & 781 & $87 \%$ \\
\hline
\end{tabular}

\section{Levels of evaluation}

Three levels of evaluation were examined along the years: (1) The single student in each year; (2) All students in each PDS partnership in each year; (3) All students in all the PDS partnerships together in the same year. ${ }^{34}$ In this article additional level has been examined and presented - the multiyear evaluation of all the students in all PDS partnerships.

\section{Findings and discussion}

In general, the findings show that in all four evaluation levels and in all the statements the student teachers evaluated the contribution of the PDS components to their learning of teaching in the first year of the partnership 2010, as moderate to high (Fig. 1). In this year the program was just beginning. The main concern was to understand the nature of the partnership in its components and the structuring of the partnership.

${ }^{34}$ A study in level 3 conducted in the context of the mentioned university - school partnership in Israel: D. Maskit, L. Orland-Barak, University - school partnerships: student teachers' evaluations across nine partnerships in Israel, Journal of Education for Teaching, 2015, 41(3), p. 285-306. 


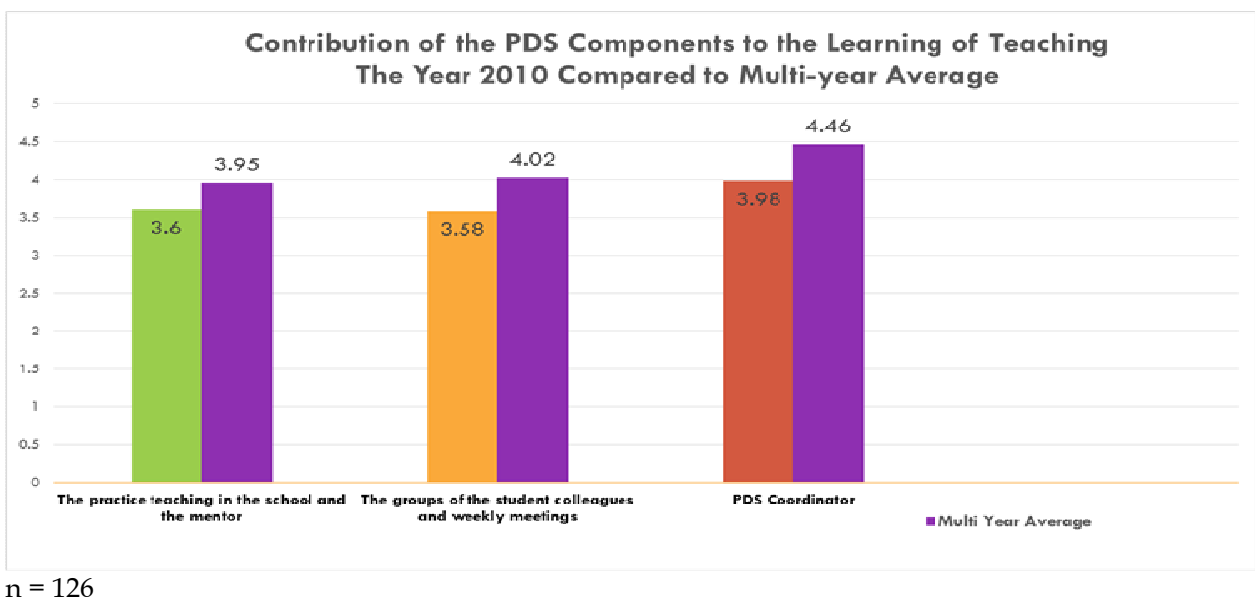

Range: $1-5$

Fig. 1. The student teachers' evaluation of the contribution of the three PDS components to their learning of teaching - The year 2010 compared to the multi-year average

From the year of 2011 to 2016 the student teachers evaluated the contribution of all partnership components to their learning of teaching as high. The average scores range is between 3.85 to 4.53, ignoring 2010 (Fig. 2).

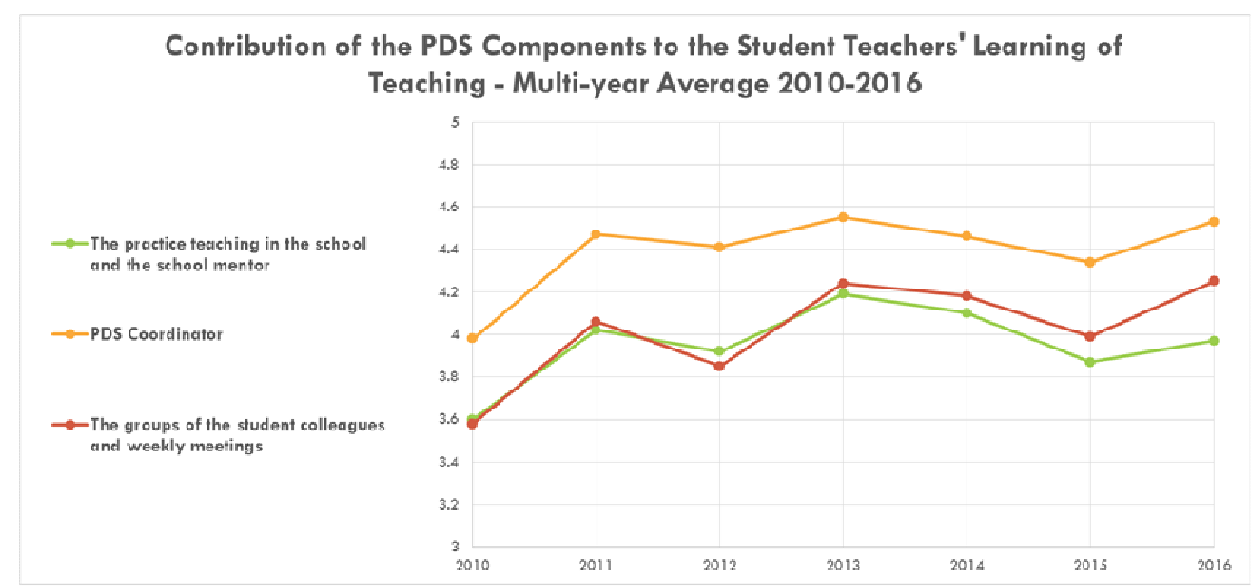

$\mathrm{n}=781$

Range: $1-5$

Fig. 2. Multi-year average of the student teachers' evaluation of the contribution of the three PDS components to their learning of teaching - The years 2010-2016 
The research shows the strengths of training according to the PDS model. The practice teaching in the school and the school mentors contributed greatly to the students in the process of training and entry into the teaching profession, in the development of professional responsibility as a teacher, in the deepening of knowledge in the subject matter and the familiarity with the curricula, in the development of skills in the field of class management, students assessment and in individualized work with students (Fig. 3). These findings are important since they provide an answer to the component of practice, which is central in the teacher training, based on the understanding that the knowledge of the teaching is acquired and develops primarily through the practical training. ${ }^{35}$ Similar findings indicated by the PDS research studies. ${ }^{36}$

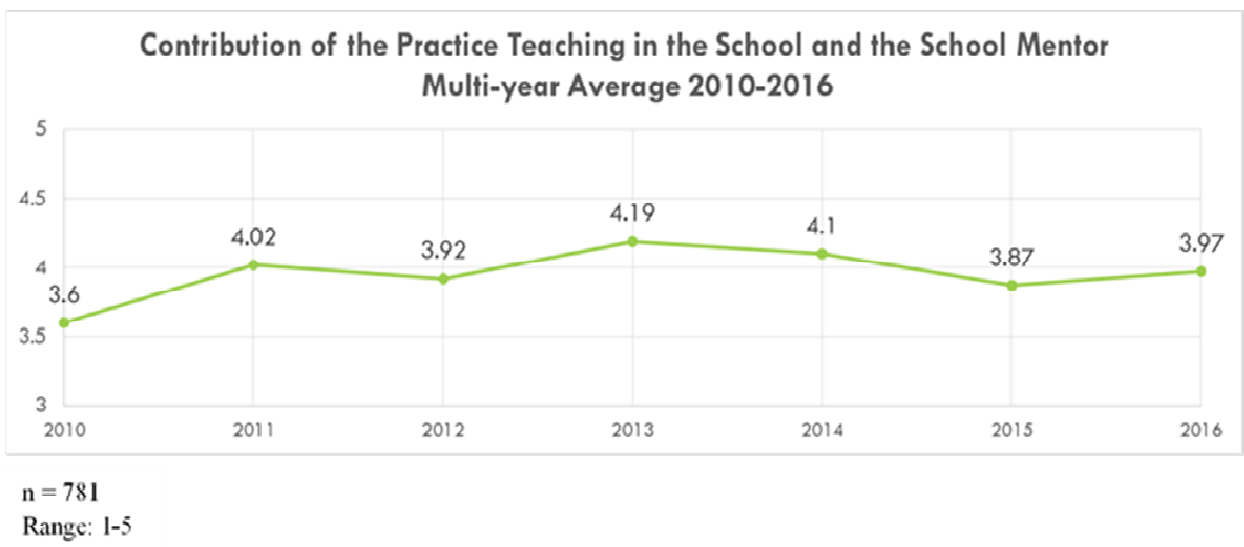

Fig. 3. Multi-year average of the student teachers' evaluation of the contribution of the practice teaching in the school and the school mentors to their learning of teaching - The years 2010-2016

The findings of the multi-year research show that the contribution of the groups of the student colleagues as learning communities, belonging to the different disciplines, and their weekly meetings are high during the partnership

${ }^{35}$ M. Zilbershtein, R. Panvevsky, E. Goz, The triangle of instruction: pedagogical instructorstudent-mentor teacher, a recipe for success or failure, Tel Aviv 2005.

${ }^{36} \mathrm{~J}$. Buitink, What and how do student teachers learn during school-based teacher education, Teaching and Teacher Education, 2009, 25(1), p. 118-127; J.M. Allen, A. Ambrosetti, D. Turner, How school and university supervising staff perceive the pre-service teacher education practicum: A comparative study, Australian Journal of Teacher Education, 2013, 38(4); L.M. Anderson, J.A. Stillman, Student teaching's contribution to preservice teacher development: A review of research focused on the preparation of teachers for urban and high-needs contexts, Review of Educational Research, 2013, 83(1), p. 3-69. 
years 2011-2016 (Fig. 4). This component contribute to the process of the student teachers' entry into the teaching profession and the development of new thinking processes on the teaching profession, to the development of teamwork, to reflective thinking about what occurs during the practice day in teaching in its different aspects, to the comprehensive familiarity with the school system and with role-holders in the school, to the development of skills for integration in the school and skills in the field of class management. The groups of the student colleagues and their weekly meetings constitute a place and source for support, enrichment, and multidimensional and multidisciplinary thinking on topics related to the teaching profession. The presented findings are commensurate with the importance arising from the literature of teacher training in the framework of learning community. The community of learners promotes the student teachers' learning, the examination of knowledge, and the creation of new understanding from different and multidisciplinary viewpoints, occur through reflective metacognitive processes. ${ }^{37}$

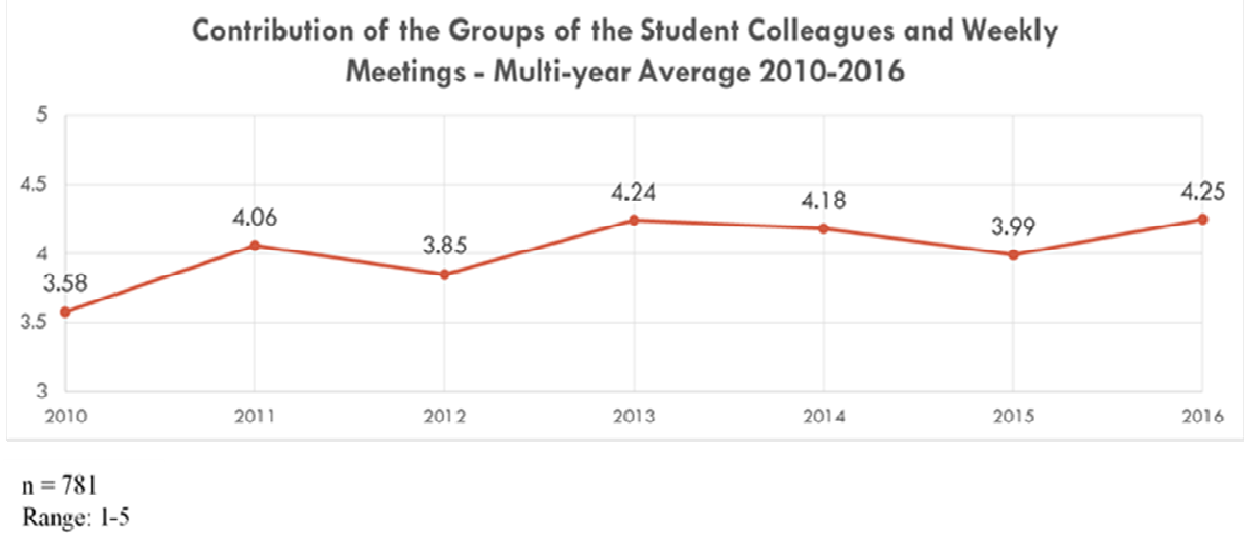

Fig. 4. Multi-year average of the student teachers' evaluation of the contribution of the groups of the student colleagues as learning communities and their weekly meetings to their learning of teaching - The years 2010-2016

The multi-year study attributes the highest evaluation over all the years of the implementation of the PDS model to the contribution of the university coordinator to the student teachers' learning of teaching (Fig. 5). The coordinator contributes to the process of the training of the student and entry into the teaching profession, to the development of the student's professional

${ }^{37}$ M.T. Buchanan, L.J. Stern, Pre-service teachers' perceptions of the peer review. 
identity and the professional responsibility as a teacher, to the student's knowledge of the school system and the role-holders in the school, to the development of skills of teamwork and integration in the school and skills in the field of class management. He contributes to the development of reflective abilities, a significant component in the practice experience, and to the encouragement of critical thinking. The PDS coordinator constitutes a source of personal and professional advice and support. It is apparent that the PDS coordinator is a central figure in the partnership model, as indicated by the PDS research studies. ${ }^{38}$ The coordinator's role is steadily forming through the construction of the partnership with the school. This research study emphasizes the coordinator's significant contribution to the promotion of the teaching students' learning and about his contribution to their professional development.

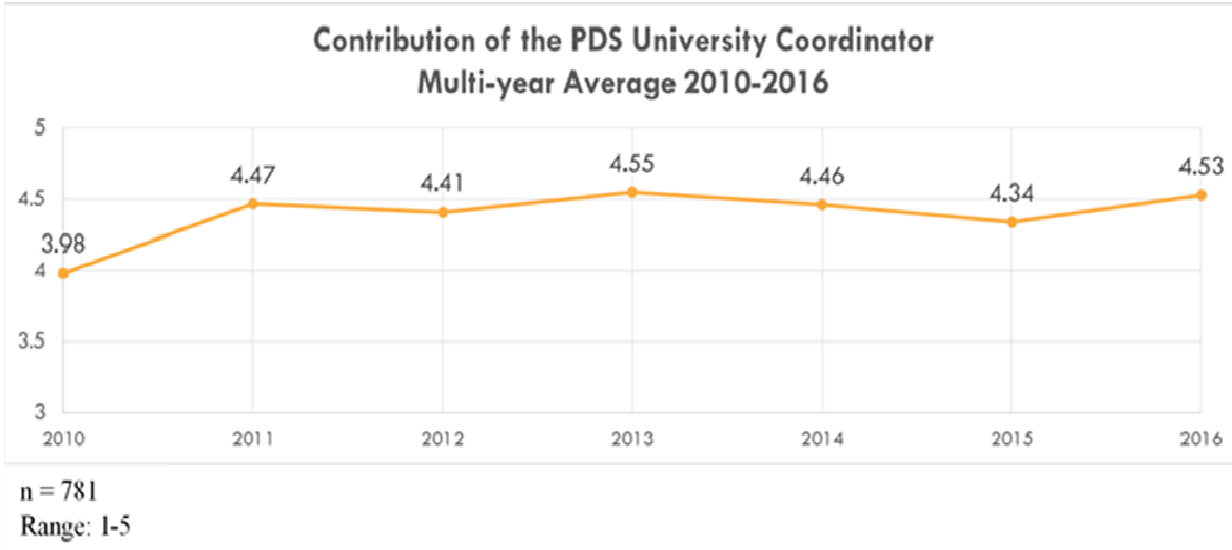

Fig. 5. Multi-year average of the student teachers' evaluation of the contribution of the PDS university coordinator to their learning of teaching - The years 2010-2016

The statements addressing the contribution of the training in the PDS model to the linkage between the theory learned in the academia and the practice in the field deserve special attention as the findings obtained are medial, and are the lowest of all statements in all the partnerships throughout all years (Fig. 6). The desire was for the partnership to bridge between the academic culture and the school culture that represents the practice, as the linkage between theory and practice is one of the weaknesses in the in

38 S. Milat, The pedagogical instructor; M. Zilberstein, M. Ben Peretz, From individual cases to the shared elements. 
the traditional model of teacher training. ${ }^{39}$ The findings indicate this topic still constitutes a challenge for the partnerships.

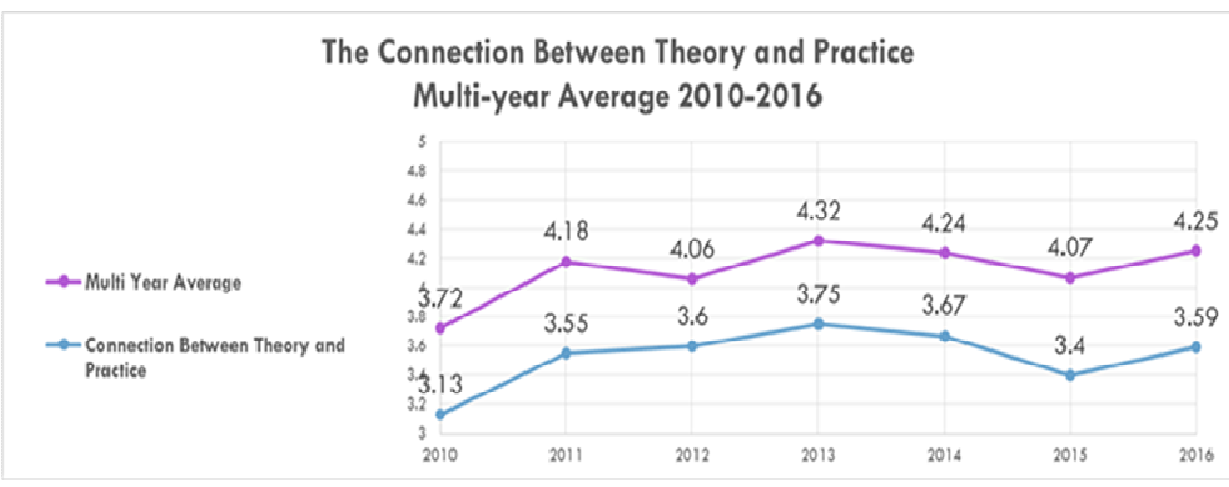

$\mathrm{n}=781$

Range: 1-5

Fig. 6. Multi-year average of the student teachers' evaluation of the contribution of the PDS teacher training to the connection between theory and practice - The years 2010-2016

\section{Summary}

The multi-year findings of the student teachers' evaluation regarding the contribution of the three PDS components to their learning of teaching are high with minor variations between schools and along the years. Teacher training according to the PDS model - the partnership model, constitute a place and source for support, and an opportunity for learning and professional development of the student teachers. The presented study strengthen findings of evaluation studies conducted on teacher training according to the PDS model. ${ }^{40}$ A substantial difficulty of the teacher training is the connection between the academia and the practice in the field. The academia in Israel is dealing with this difficulty and discover that, even in the newest programs of teacher training implemented in Israel in the past two years, that are

${ }^{39}$ M. Zilberstein, M. Ben Peretz, From individual cases to the shared elements; S. Avdor, The changed required in the characteristics of the candidates for teaching; A. Kizel, Pedagogies of reflection.

40 B.G. Gimbert, The power of multiple mentoring in the context of a PDS school: E pluribus Unum - out of many-one, Seatle 2001; D.S. Ridley, S. Hurwitz, R.D. Hackett, K.K. Miller, Comparing PDS and campus-based preservice teacher preparation: Is PDS-based preparation really better? Journal of Teacher Education, 2005, 56(1), p. 46-56; J.J. Buitink, What and how do student teachers learn; M. Allen, A. Ambrosetti, D. Turner, How school and university supervising staff; L.M. Anderson, J.A. Stillman, Student teaching's contribution to preservice teacher development. 
based on an increased stay of students in the schools, the academia-field linkage is still the weak link and is thus forms a major challenge for the future.

It is noteworthy that discussions with all the partners indicate that the implementation of teacher training according to the PDS model is complex. Occasionally there are disagreements between the partners who come from different cultures, gaps in the role expectations and in the pedagogical expectations, short-circuits in communication, feeling of great load without appropriate compensation, lack of time for orderly meetings to guide students, inadequate training of the mentors for their role, unsuitable physical and technical conditions such as a place for student meetings and a schedule suited for the practice day, and recruitment of commitment of schools over time. Most researches performed in Israel indicate similar difficulties, and this is a great challenge facing this program. It is recommended to conduct further studies that will evaluate the PDS university partnership program in Israel from the perspective of school principals, school mentors, PDS coordinators, and other key persons involved in the program.

Operating and implementation of the PDS model require dedication of considerable efforts. It is also important to conduct a further researches that will examine the quality of the teaching of the university graduates in Israel who were trained for teaching in the PDS model and to perform a comparative research that will examine whether there are differences in the quality of the teaching between the university graduates in Israel who were trained for teaching according to the PDS model and the teacher training graduates who were trained according to the traditional model.

\section{BIBLIOGRAPHY}

Allen J.M., Ambrosetti A., Turner D., How school and university supervising staff perceive the pre-service teacher education practicum: A comparative study, Australian Journal of Teacher Education, 2013, 38, 4.

Anderson L.M., Stillman J.A., Student teaching's contribution to preservice teacher development: A review of research focused on the preparation of teachers for urban and high-needs contexts, Review of Educational Research, 2013, 83, 1.

Ariav T., The training for teaching: A picture of the situation in the world and in Israel and a look to the future, [in:] The crisis in teacher education: reasons, problems and possible solution, Eds D. Kfir, T. Ariav, Van Leer Jerusalem Institute and Hakibbutz Hameuchad Publishing House, Tel Aviv 2008. (Hebrew)

Ariav T., Smith K., Creation of partnerships between teacher education institutions and the field: An international look with emphasis on the professional development school (PDS), [in:] New trend in the training programs of teachers: partnership between colleges and schools - the Is- 
raeli story, Eds M. Zilbershtein, M. Ben-Peretz, N. Greenfeld, Mofet Institute, Tel Aviv 2006. (Hebrew)

Avdor S., The changed required in the characteristics of the candidates for teaching, in their training and in their professional development, [in:] The crisis in teacher education: Reasons, problems and possible solution, Eds D. Kfir, T. Ariav, Van Leer Jerusalem Institute and Hakibbutz Hameuchad Publishing House, Tel Aviv 2008. (Hebrew)

Beck S., Is training really unnecessary? On the uniqueness of academic training of teachers, [in:] The crisis in teacher education: Reasons, problems and possible solution, Eds D. Kfir, T. Ariav, Van Leer Jerusalem Institute and Hakibbutz Hameuchad Publishing House, Tel Aviv 2008. (Hebrew)

Buchanan M.T., Stern L.J., Pre-service teachers' perceptions of the peer review, Journal of Education for Teaching, 2012, 38, 1.

Buitink J., What and how do student teachers learn during school-based teacher education, Teaching and Teacher Education, 2009, 25, 1.

Darling-Hammond L., Hammerness K., The design of teacher education programs, [in:] Preparing teachers for a changing world: What teachers should learn and be able to do, Eds L. Darling-Hammond, J. Bransford, Jossey-Bass, San-Francisco 2005.

Gimbert B.G., The power of multiple mentoring in the context of a PDS school: E pluribus Unum - out of many-one, Paper Presented at the AERA annual meeting, Seatle 2001.

Goodlad J., Educational renewal: Better teachers, better schools, Jossey-Bass, San Francisco 1994.

Holmes Group, Tomorrow's teachers. A report of the Holmes Group. East Lansing, MI: Holmes Group, 1986.

Holmes Group, Tomorrow's schools: Principles for the design of professional development schools, East Lansing, MI: Holmes Group, 1990.

Kizel A., Pedagogies of reflection: Dialogical professional-development schools in Israel, [in:] International teacher education: Promising pedagogies, Part A (Advances in Research on Teaching, Volume 22), Eds C.J. Craig, L. Orland-Barak, Emerald Group Publishing Limited, 2014.

Korthagen F., Kessels J., Linking Theory and Practice: Changing the Pedagogy of Teacher Education, Educational Researcher, 1999, 28, 4.

Levine M., Why invest in professional development schools? Educational Leadership, 2002, 65, 6. Lieberman A., Networks as learning communities, Journal of Teachers Education, 2000, 51.

Maskit D., Orland-Barak L., University - school partnerships: student teachers' evaluations across nine partnerships in Israel, Journal of Education for Teaching, 2015, 41(3).

Milat S., The Pedagogical instructor - A main figure in the creation of partnership between the colleges and the schools (PDS), [in:] A new review of the learning program of the specialization in pedagogical instruction: Work paper number 2, Eds M. Zilbershtein, R. Reichenberg, Mofet Institute, Tel Aviv 2005. (Hebrew)

Nikitina S., Pathways of interdisciplinary cognition, Cognition and Instruction, 2005, $23,3$.

Orland-Barak L., Learning to mentor-as-praxis: Foundations for a curriculum in teacher education, Springer, New York 2010.

Ridley D.S., Hurwitz S., Hackett R.D., Miller K.K., Comparing PDS and campus-based preservice teacher preparation: Is PDS-based preparation really better? Journal of Teacher Education, 2005, 56, 1.

Sagee H., Individualized mentoring as a developing initiative during the training of the students for teaching, [in:] Everything is a matter of initiative: Initiatives that promote professional 
developments in field-college partnership settings, Eds A. Kliger, A. Hoffman, Mofet Institute, Tel Aviv 2013. (Hebrew)

Schon D.A., Coaching reflective teaching, [in:] Reflection in teacher Education, Eds P.P. Griment, G.L. Erikson, Teachers' College Press, New York 1988.

Shulman L.S., Knowledge and teaching: Foundations of the new reform, Harvard Educational Review, 1987, 57, 1.

Waege K., Haugalokken O., Research-based hands-on practical teacher education: An attempt to combine the two, Journal of Education for Teaching, 2013, 39, 2.

Wenger E., Communities of practice: Learning, meaning and identity, Cambridge University Press, Cambridge 1998

Zellermayer M., Partnership as a professional research learning community: Review of the literature, [in:] In First person: Partnership in the college field, Eds A. Margolin, M. Zellermayer, Mofet Institute and Levinisky College, Tel Aviv 2005. (Hebrew)

Zilberstein M., Ben Peretz M., From individual cases to the shared elements in the constellation of the creation of partnerships, [in:] New trend in the training programs of teachers: Partnership between colleges and schools - the Israeli Story, Eds M. Zilbershtein, M. Ben-Peretz, N. Greenfeld, Mofet Institute, Tel Aviv 2006. (Hebrew)

Zilbershtein M., Panvevsky R., Goz E., The triangle of instruction: Pedagogical instructorstudent-mentor teacher, a recipe for success or failure, Mofet Institute, Tel Aviv 2005. (Hebrew) 